Supremasi Hukum : Jurnal Penelitian Hukum

p-ISSN: 1693-766X ; e-ISSN: 2579-4663, Vol. 28, No. 2, Agustus 2019, 187-203

\title{
SINERGITAS INDUSTRI KREATIF BERBASIS HAK KEKAYAAN INTELEKTUAL DALAM MENUNJANG PARIWISATA
}

\author{
Ganefi, Ganefi \\ Fakultas Hukum, Universitas Bengkulu \\ ganefii88@gmail.com
}

\begin{abstract}
This writing aims to review and explain the cooperation or synergy of creative economic actors with various parties in developing and protecting Intellectual Property Rights in the creative industries in supporting tourism. This article is the writing of normative law using the legislative approach method. The results of the study indicate that the growth of the creative industries in Indonesia is quite rapid in various fields. Industries based on creativity and creativity require legal development and protection. This can be done through the cooperation of various parties both the government, the business community, and society. But the reality in practice is not yet running optimally. Coaching from the government has not been maximized because the creative economic actors are generally young people and micro-small businesses that do not have legality; Likewise, the business world, especially banks and the public as consumers have not yet optimally rewarded the products of creativity.
\end{abstract}

Keywords: Creative Industry; Intellectual Property; Synergy; Tourism;

\section{Abstrak}

Penulisan ini bertujuan untuk mengkaji dan menjelaskan kerjasama atau sinergitas pelaku ekonomi kreatif dengan berbagai pihak dalam pengembangkan dan melindungi Hak Kekayaan Intelektual industri kreatif dalam menunjang pariwisata. Artikel ini merupakan penulisan hukum normatif dengan metode pendekatan perundang-undangan. Hasil kajian menunjukkan bahwa pertumbuhan industri kreatif di Indonesia cukup pesat dalam berbagai bidang. Industri yang berbasis daya cipta dan daya kreativitas memerlukan pengembangan dan perlindungan hukum. Hal tersebut dapat dilakukan melalui kerjasama berbagai pihak baik pemerintah, dunia usaha maupun masyarakat. Namun kenyataan dalam praktik belum berjalan secara optimal. Pembinaan dari pemerintah belum maksimal karena pelaku ekonomi kreatif umumnya adalah kaum muda dan usaha mikro kecil yang belum memiliki legalitas. Demikian pula dunia usaha terutama perbankan dan masyarakat sebagai konsumen belum memberikan penghargaan secara optimal terhadap produkproduk hasil kreativitas.

Kata Kunci: Industri Kreatif; Kekayaan Intelektual; Sinergitas; Pariwisata;

\section{PENDAHULUAN}

Perekonomian Indonesia selama ini bertumpu pada sumber daya alam yang menjadi kekayaan Negara. Dengan berkembangnya sektor pariwisata maka berkembang pula industri kreatif yang mendukung sektor tersebut. Ekonomi kreatif yang digerakkan oleh kaum muda dan Usaha Mikro Kecil dan Menengah (UMKM) berkembang cukup pesat. Hal ini sangat berpengaruh terhadap pertumbuhan perekonomian nasional. Sebagaimana dikatakan Mary Elka

Ganefi, Sinergitas Industri Kreatif Berbasis Hak Kekayaan Intelektual Dalam Menunjang Pariwisata 
Supremasi Hukum : Jurnal Penelitian Hukum

p-ISSN: 1693-766X ; e-ISSN: 2579-4663, Vol. 28, No. 2, Agustus 2019, 187-203

Pangestu, bahwa secara nasional ekonomi kreatif menyumbang 7,6 persen dari produk domentik Bruto (PDB) dan 7,5 persen pada angkatan kerja. ${ }^{1}$

Ekonomi kreatif (ekraf) memiliki potensi cukup besar untuk dikembangkan dan dapat menjadi andalan perekonomian nasional. Ekonomi kreatif merupakan industri yang menghasilkan berbagai produk yang mempunyai keterkaitan dengan proses perwujudan suatu ide atau gagasan menjadi suatu kekayaan intelektual yang memiliki nilai ekonomi tinggi bagi kesejahteraan dan lapangan pekerjaan masyarakat serta dapat meningkatkan pertumbuhan ekonomi suatu negara. ${ }^{2}$ Ekonomi kreatif lahir dari industri kreatif. Ekonomi kreatif diformulasikan sebagai kegiatan ekonomi yang mencakup industri dengan kreativitas sumber daya manusia (SDM) sebagai aset utama untuk menciptakan nilai tambah ekonomi. ${ }^{3}$

Menurut Mira Nurfitriya (2016), yang dikutip oleh Afni Regita Cahyani mengatakan bahwa nilai tambah ekonomi akan menciptakan upaya daya saing ekspor, yaitu kemampuan suatu negara untuk mengekspor atau memproduksi barang dan jasa dari suatu negara atau industri tertentu dari segi nilai yang memenuhi uji pasar internasional sekaligus untuk mempertahankan dan memperluas pendapatan riil, baik pangsa pasar domestik maupun pasar ekspor, serta meningkatkan kesejahteraan masyarakat. ${ }^{4}$ Oleh karena itu Bekraf (Badan Ekonomi Kreatif) tahun 2018 menargetkan kontribusi ekonomi kreatiif mencapai Rp 1.041 triliun dan industri kreatif diharapkan menyerap 18,2\% tenaga kerja serta menyumbang US\$23,7 miliar ekspor nasional. Sedangkan tahun 2019, ditargetkan senilai Rp 1.123 triliun terhadap PDB dan menyumbang ekspor US\$ 25,1 miliar. Hal ini menurut Triawan Munaf (Kepala Bekraf) bahwa gagasan kreatif tak akan pernah habis sehingga diharapkan dapat menggantikan sumber daya alam (SDA) menjadi tulang punggung perekonomian nasional. 5

Dalam upaya mencapai hal tersebut diperlukan kerjasama semua pihak baik dunia usaha, pemerintah maupun masyarakat. Hal tersebut sangat penting karena pelaku ekonomi kreatif umumnya adalah generasi muda dan Usaha Mikro Kecil dan Menengah yang memiliki berbagai keterbatasan. Untuk itu campur tangan pemerintah sangat dibutuhkan dalam mendorong kemajuan Ekkraf melalui pembinaan dalam berbagai hal. Demikian pula dunia usaha dan masyarakat dalam mendukung pengembangan pariwisata di Indonesia. Dalam konteks

1 Jeni Susyanti, Model Pendampingan Sektor Paeriwisata Secara Integratif, Studi Kasus Pada Pelaku Bisnis Ekonomi Kreatif di Malang, Seminar Nasional Riset Inovatif II, Tahun 2014, ISSN: 2339-1553

2 Departemen Perdagangan Republik Indonesia, Pengembangan Ekonomi Kreatif Indonesia 2025, Jakarta, Depdag RI, 2008, hlm. 2

II $b$ id.

4 Afni Regita Cahyani, Strategi Indonesia Dalam Mendorong Sustainable Competitive Advandtage Ekonomi Kreatif Subsektor Fashion: Kebijakan Industri dan Diplomasi Perdagangan, Universitas Gajah Mada, Tesis, 2018, diunduh tanggal 26 Januari 2019 dari http://etd.repository.ugm.ac.id/

5 Desi Setyowati; Metta Dharmasaputra; Pingit Ario, "Bekraf Targetkan Industri Kreatif Sumbang PDB Rp 1.000 Triliun", diunduh tanggal 27 Januari 2019 dari https://katadata.co.id/berita/2018/02/26/bekraf-targetkan-industrikreatif-sumbang-pdb-rp-1000-triliun

Ganefi, Sinergitas Industri Kreatif Berbasis Hak Kekayaan Intelektual Dalam Menunjang Pariwisata 
Supremasi Hukum : Jurnal Penelitian Hukum

p-ISSN: 1693-766X ; e-ISSN: 2579-4663, Vol. 28, No. 2, Agustus 2019, 187-203

tersebut persoalan yang dikaji dalam tulisan ini adalah bagaimana peran berbagai pihak dalam bersinergi dengan pelaku ekonomi kreatif mendukung pengembangan pariwisata di Indonesia. Oleh karena itu tulisan ini bertujuan untuk mengkaji dan menjelaskan peran berbagai pihak baik pemerintah, dunia usaha dan masyarakat dalam bersinergi untuk mengembangkan ekonomi kreatif. Selain itu juga untuk memberikan perlindungan hasil cipta dan karya para pelaku ekonomi yang berbasis hak kekayaan intelektual.

Kemudian tulisan ini merupakan hasil penelitian hukum yang menggunakan metode penelitian hukum doktrinal dengan pendekatan perundang-undangan dan konseptual. Bahan-bahan hukum yang digunakan bersumber dari bahan hukum primer, bahan hukum sekunder dan tersier, yang dikumpulkan dengan cara studi kepustakaan.

\section{HASIL DAN PEMBAHASAN}

\section{Pariwisata Sebagai Suatu Industri Kreatif}

Pariwisata merupakan suatu industri yang berkembang pesat di Indonesia. Selain sumberdaya alam Indonesia juga memiliki potensi pariwisata baik dari yang dapat dikembangkan baik dari aspek alam, sejarah maupun sumberdaya manusia. Menurut Menteri Pariwisata berdasarkan versi The World Travel \& Tourism Council (WTTC), Indonesia merupakan negara dengan pertumbuhan pariwisata teringgi nomor sembilan (9) di dunia. Pada tahun 2017 pertumbuhan pariwisata Indonesia mencapai 22 persen diatas rata-rata pertumbuhan wisatawan dunia 6,4 persen dan ASEAN 7 persen. Dibandingkan dengan negara-negara Asean lainnya Indonesia jauh lebih tinggi dari Malaysia 4 persen, Singappura 5,8 persen dan Thailand 8,7 persen. Pariwisata menjadi sektor penghasil devisa terbesar penyumbang devisa nasional keempat setelah kelapa sawit (CPO), minyak dan gas bumi serta pertambangan (batu bara) ${ }^{6}$

Dalam Undang-Undang Nomor 9 Tahun 1990 tentang Pariwisata, Pasal 1 angka (3) bahwa Pariwisata adalah segala sesuatu yang berhubungan dengan wisata, termasuk pengusahaan objek dan daya tarik wisata serta usaha-usaha yang terkait bidang tersebut. Sedangkan wisata menurut kamus Besar Bahasa Indonesia berarti bepergian bersama atau piknik. Sementara itu dalam Pasal 1 angka (1) UU Kepariwisataan adalah kegiatan perjalanan atau sebagian dari kegiatan tersebut yang dilakukan secara sukarela serta bersifat sementara untuk menikmati objek dan daya tarik wisata. Demikian pula usaha pariwisata adalah kegiatan yang bertujuan menyelenggarakan jasa pariwisata, menyediakan atau mengusahakan objek dan daya tarik wisata, usaha sarana pariwisata dan usaha lain yang terkait di bidang tersebut (angka 5).

Menurut Caretourism, Sektor pariwisata adalah sekumpulan unit produksi dalam industri berbeda yang menyediakan barang dan jasa yang khususnya

6 Tulus Wijanarko, Pertumbuhan Pariwisata Indonesia Peringkat 9 Di Dunia, Harian Tempo.co, Selasa 23 Oktober 2018, diunduh tanggal 20 April 2019 dari https://travel.tempo.co/read/1139099/pertumbuhan-pariwisataindonesia-peringkat-9-di-dunia

Ganefi, Sinergitas Industri Kreatif Berbasis Hak Kekayaan Intelektual Dalam Menunjang Pariwisata 
Supremasi Hukum : Jurnal Penelitian Hukum

p-ISSN: 1693-766X ; e-ISSN: 2579-4663, Vol. 28, No. 2, Agustus 2019, 187-203

dibutuhkan para pengunjung. Sektor pariwisata sebagai kegiatan perekonomian telah menjadi andalan potensial dan prioritas pengembangan bagi sejumlah negara, terlebih bagi negara berkembang seperti Indonesia yang memiliki potensi wilayah yang luas dengan daya tarik wisata yang cukup besar, banyaknya keindahan alam, aneka warisan sejarah budaya, dan kehidupan masyarakat (etnik). ${ }^{7}$

Kegiatan pariwisata merupakan kegiatan berkenaan dengan usaha memenuhi kebutuhan hidup manusia untuk memperoleh kesenangan. Kesenangan itu dinikmati berkat adanya jasa yang diberikan oleh pihak tertentu. Pariwisata itu sendiri adalah suatu industri. Sesuai dengan istilahnya, pengertian industri menurut A.S. Hornby (1978:22) adalah The quality of working hard, the production of goods, the creation of wealth by human efforts. Kegiatan industri memerlukan kerja keras agar berhasil, yang akan memberikan sejumlah produk yang akan memberikan kepuasan dan kesejahteraan kepada manusia. Itu sebabnya kata industri senantiasa mengandung pengertian suatu usaha yang menghasilkan produk. Produk itu merupakan rangkaian jasa-jasa yang mempunyai segi ekonomis, sosial dan psikologis. ${ }^{8}$

Dari beberapa pengertian dalam undang-undang tersebut dapat dikatakan bahwa pariwisata lebih merupakan aktivitas bisnis di bidang jasa. Selain tempat sebagai kawasan tujuan wisata juga diperlukan berbagai aspek untuk mendukung kegiatan pariwisata. Dibutuhkan kreativitas dari ide-ide manusia untuk mengembangkan suatu tempat menjadi kawasan tujuan wisata. Oleh karena itu bisnis pariwisata pada umumnya menghasilkan produk-produk kreatif dari sumberdaya manusia. Indonesia selain memiliki kekayaan alam yang potensial, juga memiliki sumberdaya manusia yang jumlahnya cukup besar. Pengembangan kreativitas sumberdaya manusia melalui industri pariwisata akan menghasil produk-produk wisata yang memiliki nilai ekonomi tinggi. Hal tersebut dapat merupakan potensi yang sangat penting dalam perekonomian nasional.

Menurut Oemar Hamalik, produk wisata dihasilkan oleh berbagai perusahaan seperti jasa hotel, jasa angkutan, jasa hiburan, jasa penyelenggaraan tour dan sebagainya. Disediakan oleh masyarakat antara lain jalanan dan keramahtamahan rakyat. Disediakan oleh alam seperti pemandangan alam, pantai, lautan dan sebagainya. Jasa-jasa itu merupakan rangkaian yang saling berkaitan satu sama lain dan merupakan satu kesatuan yang disebut "Package"). 9 M.J. Projogo (1973:22) menyebutkan bahwa industri pariwisata itu adalah merupakan suatu proses kegiatan ekonomi di bidang kepariwisataan yang produknya berupa jasa-jasa (services) untuk memenuhi kebutuhan wisatawan

7 Alfiah Mudrikah; Dewi Sartika; Rahma Yuniarti; Ismanto; Akbar Budi Satia, Kontribusi Sektor Pariwisata Terhadap Gdp Indonesia Tahun 2004 - 2009, Economics Development Analysis Journal (EDAJ) 3 (2) (2014), hlm. 365

8 Lukman Hakim, Industri Pariwisata Dan Pembangunan Nasional, Among Makarti, Vol.3 No.5 Juli 2010, hlm. 71.

9 Oemar Hamalik, Travel dan Tour, Azas, Metode dan Teknis, Jakarta: Pradnya Paramitha, 1978, hlm. 22

Ganefi, Sinergitas Industri Kreatif Berbasis Hak Kekayaan Intelektual Dalam Menunjang Pariwisata 
Supremasi Hukum : Jurnal Penelitian Hukum

p-ISSN: 1693-766X ; e-ISSN: 2579-4663, Vol. 28, No. 2, Agustus 2019, 187-203

secara compartable (menyenangkan), privacy (betah karena tidak terganggu) dan security (terjamin keamanan pribadi) sehingga wisatawan kerasan. 10

Industri pariwisata sangat terkait dengan industri kreatif. Kedua industri ini harus berjalan seiring dan saling melengkapi. Sebagaimana ditegaskan oleh Menteri Pariwisata dan Ekonomi Kreatif Mari Elka Pangestu di Jakarta, Rabu (20/8/2014), seusai acara Forum Ekonomi Nusantara yang diselenggarakan harian Kompas dan PT Bank Negara Indonesia (Persero) Tbk. "Pariwisata tak bisa dipisahkan dari industri kreatif. Contohnya Dyandra Media International yang termasuk perusahaan penyelenggara MICE (meeting, incentive, convention, and exhibition). MICE tergolong pariwisata. Untuk menyelenggarakan pertunjukan, perusahaan MICE seperti Dyandra memerlukan industri kreatif, mulai desain pameran, membuat pertunjukan, dan sebagainya.. Usaha pariwisata secara umum seperti hotel juga melibatkan proses kreatif yang tak sedikit, mulai dari arsitek, cendera mata, kuliner, hingga seni pertunjukan." Perkembangan industri pariwisata seiring sejalan dengan industri kreatif. ${ }^{11}$

Berdasarkan data Kemenparekraf RI (2011), 3 subsektor industri kreatif yang terkait erat dengan industri pariwisata dan memberikan kontribusi cukup besar bagi perkembangan pariwisata nasional adalah kuliner $32 \%$, fesyen $28,7 \%$ dan kemudian kerajinan 14,7\%, namun pertumbuhan ketiganya masih di bawah pertumbuhan PDB Nasional. Sebagian besar yang bergerak di sektor industri kreatif tersebut merupakan kelompok UKM dengan produktivitas Rp. 19,5 juta per pekerja per tahun. ${ }^{12}$

\section{Sinergitas Hak Kekayaan Intelektual dan Industri Kreatif}

Menurut Carolyn Hotckis dalam "International Law for Bisnis" (New York :McGraw-Hill, 1994,304) yang dikutip oleh Maria Alfons, bahwa saat ini sistem hukum meletakkan kekayaan kedalam tiga kategori, pertama, sebagian besar masyarakat mengakui hak kepemilikan pribadi dalam kekayaan pribadi, yang dikenal dengan in tangible things; kedua, kekayaan dalam pengertian riil seperti tanah dan bangunan; dan ketiga, kekayaan yang diketahui sebagai kekayaan intelektual. Terkait dengan KI, semua negara mengakui hak kekayaan dalam bentuk produk ide, seperti dalam bentuk hak cipta, paten, merek dan rahasia dagang, tata letak sirkuit terpadu, varietas tanaman. 13

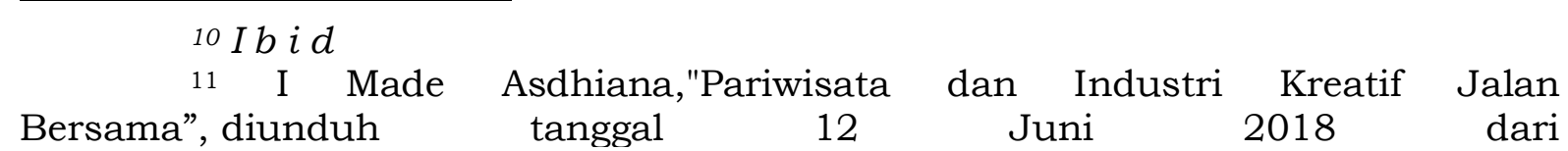
https: / / travel.kompas.com/read/2014/08/21/161000627/Pariwisata.dan.Industr i.Kreatif.Jalan.Bersama.

12 Putri Diana1*, I Ketut Suwena1, Ni Made Sofia Wijaya1, Peran Dan Pengembangan Industri Kreatif Dalam Mendukung Pariwisata Di Desa Mas Dan Desa Peliatan, Ubud, Jurnal Analisis Pariwisata ISSN : 1410 - 3729, Vol. 17 No. 2, 2017, p.85

${ }^{13}$ Maria Alfons, Implementasi Hak Kekayaan Intelektual Dalam Perspektif Negara Hukum, Jurnal Legislasi Indonesia, Vol. 14 (3) September 2017, p.303.

Ganefi, Sinergitas Industri Kreatif Berbasis Hak Kekayaan Intelektual Dalam Menunjang Pariwisata 
Supremasi Hukum : Jurnal Penelitian Hukum

p-ISSN: 1693-766X ; e-ISSN: 2579-4663, Vol. 28, No. 2, Agustus 2019, 187-203

Hak Kekayaan Intelektual pada umumnya berhubungan dengan perlindungan penerapan ide dan informasi yang memiliki nilai komersial. ${ }^{14} 12$ Secara faktual, HKI merupakan satu sistem pemberian perlindungan hukum bagi karya-karya intelektual yang mencakup jangkauan yang luas, dari pengetahuan tradisional sampai program komputer dan Internet di era bisnis digital saat ini. ${ }^{15}$ HKI merupakan hak untuk menikmati hasil kreativitas intelektual manusia secara ekonomis. ${ }^{16}$

Industri pariwisata menurut Arjana (2015) adalah industri yang menghasilkan produk atau barang dan jasa melibatkan berbagai bidang kegiatan ekonomi yang produktif untuk mendukung usaha di bidang pariwisata, baik langsung maupun tidak langsung. Usaha ekonomi kreatif merupakan kegiatan ekonomi produktif yang berkembang dengan pesat di sektor pariwisata. ${ }^{17}$

Konsep ekraf merupakan sebuah konsep ekonomi di era ekonomi baru yang mengintensifkan informasi dan kreativitas dengan mengandalkan sumber daya buatan berupa ide dan stock of knowledge dari sumber daya manusia sebagai faktor produksi utama dalam kegiatan ekonominya. ${ }^{18}$ Industri kreatif di Indonesia didefinikan dalam buku Pengembangan Ekraf Nasional 2009-2015 yaitu: "Industri yang berasal dari pemanfaatan kreativitas, ketrampilan serta bakat individu untuk menciptakan kesejahteraan serta lapangan pekerjaan melalui penciptaan dan pemanfaatan daya kreasi dan daya cipta individu tersebut. Ekraf merupakan penciptaan nilai tambah (ekonomi, sosial, budaya, lingkungan) berbasis ide yang lahir dari kreativitas sumber daya manusia (orang kreatif) dan berbasis pemanfaatan ilmu pengetahuan, termasuk warisan budaya dan teknologi. 19

Kreativitas merupakan roh dalam industri kreatif, untuk dapat bertahan, industri kreatif perlu menjaga dan mengembangkan kreativitasnya. Industri kreatif yang terjaga dan berkembang kreativitasnya akan mampu beradaptasi dalam persaingan pasar yang sangat ketat. Untuk itu perlu perlindungan hukum terhadap Hak Kekayaan Intelektual. Berkaitan dengan teori perlindungan hukum Hak Kekayaan Intelektual, Robert C. Sherwood sebagaimana dikutip oleh Muhammad Fahmi Rois, Kholis Roisah ${ }^{20}$ mengatakan bahwa pelaku industri

14 Tim Lindsey, dkk. (editor), Hak Kekayaan Intelektual Suatu Pengantar, Bandung: PT. Alumni, 2011, hlm. 3.

15 Abdul Rasyid Saliman, Hukum Bisnis untuk Perusahaan: Teori dan Contoh Kasus, Edisi kedua, Cetakan ke-6, Jakarta: Prenada Media Group, 2011, hlm. 144.

16 Sudaryat, dkk., Hak Kekayaan Intelektual, Cetakan I, Bandung: Oase Media, 2010, hlm. 15.

17 Putri Kusuma Sanjiwani, Hak Kekayaan Intelektual Dalam Industri Pariwisata Studi Kasus: Perlindungan Hukum Pemanfaatan Local Genius dalam Produk Pengusaha Lokal, Jurnal Imiah Hospitality Management ISSN 2087 - 5576 Vol. 7 No. 1, Desember 2016, p.14

18 Sulasi Rongiyati, Pelindungan Hukum Hak Kekayaan Intelektual Pada Produk Ekonomi Kreatif, Jurnal NEGARA HUKUM: Vol. 9, No. 1, Juni 2018, p. 45

19 I b id.

20 Muhammad Fahmi Rois, Kholis Roisah, Perlindungan Hukum Kekayaan Intelektual Kerajinan Kuningan Tumang, Kanun Jurnal Ilmu Hukum, Ganefi, Sinergitas Industri Kreatif Berbasis Hak Kekayaan Intelektual Dalam Menunjang Pariwisata 
Supremasi Hukum : Jurnal Penelitian Hukum

p-ISSN: 1693-766X ; e-ISSN: 2579-4663, Vol. 28, No. 2, Agustus 2019, 187-203

kreatif mendapatkan perlindungan melalui reward theory, recovery theory, incentive theory, risk theory, dan economic growth stimulus theory. Konsep tersebut masing-masing adalah: reward theory yaitu pencipta mendapatkan imbalan terhadap karya intelektual sebagai pengakuan dan penghargaan atas upaya kreatifnya. Kedua, recovery theory: berdasarkan teori ini, pencipta atau pelaku ekonomi kreatif seharusnya memperoleh kembali apa yang dikeluarkan. Ketiga, incentive theory: menyatakan bahwa insentif sangat penting untuk memacu pelaku ekonomi kreatif semakin meningkatkan karyanya intelektualnya. Keempat, risk theory: teori ini mengakui bahwa suatu ciptaan memiliki risiko untuk ditiru oleh orang lain. Untuk itu sudah seharusnya ciptaan memperoleh perlindungan hukum. Kelima, economic growth stimulus theory: pertumbuhan ekonomi dapat dilihat dari kemampuan industri kreatif sebagai industri berbasis HKI dapat menciptakan lapangan usaha dan meningkatkan perekonomian sektor riil.

Terkait dengan perlindungan hukum, Satjipto Rahardjo mengemukakan bahwa salah satu sifat dan sekaligus merupakan tujuan dari hukum adalah memberikan pelindungan (pengayoman) kepada masyarakat, dan pelindungan hukum terhadap masyarakat tersebut harus diwujudkan dalam bentuk kepastian hukum. Pelindungan hukum itu sendiri merupakan upaya melindungi kepentingan seseorang dengan cara mengalokasikan suatu kekuasaan kepadanya untuk bertindak dalam kepentinganya tersebut. ${ }^{21}$

Untuk memberikan perlindungan hukum kepada masyarakat, termasuk dengan hak kekayaan intelektual kepada pelaku ekonomi kreatif memerlukan peran serta berbagai pihak. Sinegitas antara Pemerintah, dunia usaha, masyarakat dan pelaku ekonomi kreatif sangat penting. Setidaknya ada tiga pihak yang terlibat di dalam tiga pilar pendukung ekonomi kreatif, mulai mengimplementasi industri kreatif dengan menghasilkan creativepreneur, sehingga mereka dapat melakukan bisnisnya dengan baik. Terkait dengan hal tersebut, maka untuk dapat lebih mengkomersilkan ekonomi kreatif, maka pemerintah, dunia usaha, dan intelektual mulai harus bekerjasama, termasuk dengan lembaga perbankan, sambil juga memperhatikan aspek teknologi dan sumber daya, serta mengupayakan terjadinya ruang publik yang dapat menjadi ajang bagi krativitas. ${ }^{22}$

Indonesia sebagai negara hukum pada dasarnya telah memberikan perlindungan hukum kepada masyarakat dalam berbagai aspek kehidupan termasuk termasuk ekonomi kreatif. Perlindungan dimaksud agar pemilik KI baik perorangan, kelompok atau badan usaha dapat menggunakan haknya atau mengeksplorasi kekayaannya dengan aman yang pada gilirannya dapat menciptakan iklim ekonomi dari hasil yang dikaryakannya dan dapat menciptakan

Vol. 20, No. 3, (Desember, 2018), doi: https://doi.org/10.24815/kanun.v20i3.11717, p. 401-419.

21 Satjipto Raharjo, Permasalahan Hukum di Indonesia, Bandung: Alumni, 1983, hlm. 121.

22 Caria Ningsih : Sinergitas Industri Kreatif Berbasis Pariwisata dengan Strategi Pembangunan Industri Nasional Menuju Globalisasi, Jurnal Manajemen Resort \& Leisure Vol. 11, No. 1, April 2014

Ganefi, Sinergitas Industri Kreatif Berbasis Hak Kekayaan Intelektual Dalam Menunjang Pariwisata 
Supremasi Hukum : Jurnal Penelitian Hukum

p-ISSN: 1693-766X ; e-ISSN: 2579-4663, Vol. 28, No. 2, Agustus 2019, 187-203

iklim ekonomi juga bagi negara sehingga dapat memberikan manfaat dan kesejahteraan bagi bangsanya karena adanya perlindungan. ${ }^{23}$

Kemajuan ekonomi suatu Negara juga dapat dilihat dari banyaknya perlindungan HKI yang dimilikinya. Implementasi perlindungan HKI di Indonesia banyak menemui kendala yang disebabkan oleh berbedanya karakter budaya masyarakat Indonesia yang bersifat komunal dengan karakter dari rezim HKI yang bersifat individual. ${ }^{24}$

Hak Kekayaan Intlektual di dalam konsepnya, kepemilikan yang diberikan kepada setiap pencipta atau penemu meliputi hak ekonomi dan hak moral. Hak ekonomi merupakan hak untuk memperoleh keuntungan ekonomi atas kekayaan intlektual. Pencipta atau penemu mempunyai hak yang sifatnya eksklusif hanya untuk dirinya atau orang lain yang mendapat izin dari pencipta atau penemu untuk bisa mengeksploitasi nilai -nilai ekonomi dari ciptaan tersebut, sedangkan hak moral merupakan hak eksklusif pencipta yang berisi larangan bagi pihak lain untuk mengadakanperubahan atas kreativitasnya. Hak moral ini tidak bisa dialihkan kepada siapa pun karena hak ini bersifat pribadi. Sifat pribadi dalam hak moral ini lebih cendrung pada nama baik, kemampuan, dan integritas pencipta. Hak Kekayaan Intelektual hanya dapat diberikan pemerintah kepada seseorang yang telah mampu menuangkan ide atau gagasan kedalam suatu bentuk karya yang dapat memberi manfaat dalam kehidupan masyarakat. Karya yang berasal dari akal pikiran manusia tidak dapat dibatasi ruang lingkupnya, karena ditopang oleh teknologi yang cukup modern seperti sekarang ini. Untuk itu agar memberi kemudahan dalam memahami tentang hak kekayaan intlektual kepada masyarakat, perlu dijelaskan bahwa ruang lingkup Hak Kekayaan Intlektual di Indonesia terdiri atas : Hak cipta dan hak kekayaan industri. Hak cipta meliputi hak -hak yang berhubungan dengan ilmu pengetahuan,seni dan sastra, sedangkan hak kekayaan industri terdiri dari : hak paten, hak merek, desain industri, desain tata letak sirkuit terpadu,rahasia dagang dan varitas tanaman.

Perkembangan hak kekayaan intlektual di Indonesia boleh dikatakan cukup memadai, sudah banyak undang-undang yang mengalami perubahan karena sudah tidak sesuai lagi dengan kondisi sekarang ini, namun perubahan tersebut masih banyak pihak yang mempertanyakan efektifitas keberlakuannya. Menurut Djamal dalam tulisannya yang berjudul "Pemberlakuan hukum kekayaan Intelektual Dalam Praktek Di Indonesia “ (Dilihat dari berbagai kasus ), bahwa: efektifitas pemberlakuan Hukum Kekayaan Intelektual di Indonesia dipengaruhi oleh 3 ( tiga ) faktor, yaitu kualitas perundang-undangan, aparat penegak hukum, dan pemahaman masyarakat. 25

${ }^{23}$ Maria Alfons, Op.Cit

24 Sigit Nugroho, Perlindungan Hak Kekayaan Intelektual Dalam Upaya Peningkatan Pembangunan Ekonomi Di Era Pasar Bebas Asean, Supremasi Hukum :Jurnal Penelitian Hukum, 24, No. 2, Agustus 2015

25Djamal, Pemberlakuan hukum kekayaan Intelektual Dalam Praktik Di Indonesia, International Conference Proceding, Faculty of Law ,University of Ganefi, Sinergitas Industri Kreatif Berbasis Hak Kekayaan Intelektual Dalam Menunjang Pariwisata 
Supremasi Hukum : Jurnal Penelitian Hukum

p-ISSN: 1693-766X ; e-ISSN: 2579-4663, Vol. 28, No. 2, Agustus 2019, 187-203

Dewasa ini perlindungan HKI terhadap Industri kreatif mendapat perhatian khusus karena dianggap mampu berkontribusi secara pendapatan nasional maupun daerah dan cukup mampu menyerap tenaga kerja. Setidaknya ada 14 subsektor industri kreatif yakni fesyen, pasar seni dan barang antik, permainan interaktif, film, vidio dan fotografi, kerajinan, musik, desain, periklanan, televisi dan radio, seni pertunjukan, riset dan pengembangan, layanan komputer dan piranti lunak, penerbitan dan percetakan, arsitektur. Kedepan direncanakan subsektor kuliner akan masuk ke dalam subsector industri kreatif. 26 Terdapat tiga subsektor industri kreatif yang terkait erat dengan industri pariwisata dan memberikan kontribusi cukup besar bagi perkembangan pariwisata nasional adalah kuliner $32 \%$, fesyen 28,7 \% dan kemudian kerajinan 14,7\%.27

Dalam konsideran Undang-Undang Nomor 20 Tahun 2008 tentang Usaha Mikro Kecil dan Menengah atau sering di sebut dengan istilah UMKM huruf c, sebagaimana yang dikutif oleh Mukti Fajar , bahwa: Pemberdayaan Usaha Mikro, Kecil, dan Menengah perlu diselenggarakan secara menyeluruh, optimal, dan berkesinambungan melalui pengembangan iklim yang kondusif, pemberian kesempatan berusaha, dukungan, perlindungan, dan pengembangan usaha sluasluasnya, sehingga mampu meningkatkan kedudukan, peran, dan potensi Usaha Mikro, Kecil, dan Menengah dalam mewujudkan pertumbuhan ekonomi, pemerataan dan peningkatan pendapatan rakyat, penciptaan lapangan kerja,dan pengentasan kemiskinan. ${ }^{28}$

Indonesia merupakan negara kepulauan serta memiliki potensi pariwisata yang sangat beragam. Indonesia memiliki luas $1.910 .931,32 \mathrm{~km}^{2}$ dan memiliki sekitar 17.000 pulau yang terbentang dari Sabang sampai Merauke serta memiliki jumlah penduduk 259.940.857 jiwa. Selain daripada itu pulau-pulau kecil yang merentang sepanjang $6.400 \mathrm{~km}$ dari barat ke timur dan sekitar $3000 \mathrm{~km}$ dari utara dan selatan dan oleh sebab itu, secara alamiah memberikan keanekaragaman (Prosiding Pelatihan dan Lokakarya, Perencanaan Pariwisata Berkelanjutan, 1997). Selain wilayah yang sangat luas, Indonesia didukung oleh sumber pariwisata yang sangat beragam. Dimana wisata di Indonesia memiliki beranekaragam kriteria aspek kepariwisataan. Keanekaragaman ini ditopang oleh faktor alam, budaya/kultur, sosial dan ekonomi setempat.

Di Indonesia masalah kepariwisataan menjadi perhatian semua orang terutama orang-orang yang memang gemar menikmati keindahan alam, hampir setiap daerah memiliki tempat wisata yang indah serta memiliki keunikan tersendiri yang tidak dimiliki oleh daerah lain. Selain itu banyak terdapat tempat-

Mataram in coroperation with Association of Intelectual Property Lecturer of Indonesia , 2017

26 Caria Ningsih, Sinergitas Industri Kreatif Berbasis Pariwisata Dengan Strategi Pembangunan Industri Nasional Menuju Globalisasi. Jurnal Manajemen Reseort \& Leisure, Vol.11, No.1,april 2014, p. 60

27 Putri Diana Dkk, Peran dan Pengembangan Industri Kreatif Dalam Mendukung Pariwisata Di Desa Mas dan Desa Peliatan, UBUD, Jurnal Analisis Pariwisata, Vol.17 No.2.2017, p. 85.

28 Mukti Fajar ND, UMKM Di Indonesia Perspektif hukum Ekonomi, Pustaka Pelajar, Yogyakarta, 2016, hlm 255

Ganefi, Sinergitas Industri Kreatif Berbasis Hak Kekayaan Intelektual Dalam Menunjang Pariwisata 
Supremasi Hukum : Jurnal Penelitian Hukum

p-ISSN: 1693-766X ; e-ISSN: 2579-4663, Vol. 28, No. 2, Agustus 2019, 187-203

tempat wisata yang terkenal karena mencerminkan ciri khas budaya daerahnya seperti : makanan daerah, kesenian, batik, produk tanaman, dan lain-lain. Oleh sebab itu maka setiap tempat wisata harus dijaga dan dirawat serta perlu dilestarikan keberadaannya tanpa terkecuali. Sehubungan dengan pariwisata tersebut perlu ada kesepahaman persepsi semua pihak dalam rangka menunjang kegiatan kepariwisataan.

Menurut Pasal 1 angka 4 Undang-Undang Nomor 10 Tahun 2009 tentang Kepariwisataan dijelaskan bahwa Kepariwisataan adalah keseluruhan kegiatan yang terkait dengan pariwisata dan bersifat multidimensi serta multidisiplin yang muncul sebagai wujud kebutuhan stiap orang dan negara serta interaksi antara wisatawan dan masyarakat setempat, sesama wisatawan, Pemerintah, Pemerintah Daerah dan pengusaha. Hal ini menunjukkan bahwa kepariwisatan memiliki sifat multidimensi dan multidisiplin. Kepariwisataan merupakan industri yang mencakup berbagai aspek mulai dari jasa transportasi, akomodasi perhotelan, panorama alam termasuk alam pegunungan maupun pantai, aktivitas entertainments seperti berbagai kesenian termasuk dalam perkembangan akhirakhir ini wisata budaya kuliner. Kegiatan kepariwisataan tersebut dituntut harus memenuhi kebutuhan serta harmoni dengan interaksi antara pemerintah,pengusaha industri kepariwisataan, karyawan,wisatawan, serta yang tidak kalh pentingnya masyarakat setempat, yang berorientasi tidak hanya pada masa sekarang, namun juga generasi masa datang terkait pertumbuhan ekonomi, sosial, lingkungan yang senantiasa dilihat dari kebutuhan wisatawan, industri kepariwisataan maupun masyarakat setempat. (Host community). ${ }^{29}$

Dengan perkembangan industri kreatif yang mengalami tren peningkatan dari tahun ketahun, sebagaimana dirilis oleh Kepala Badan Ekonomi Kreatif. Triawan Munaf, bahwa " Pada tahun 2015, kontribusi industri kreatif terhadap PDB tercatat sebesar 852 trilliun. Saat itu industri ini menyerap 13,9\% tenaga kerja dan menyumbang US\$ 19,4 milliar terhadap ekspor nasional. Selanjutnya, kontribusi industri kreatif tercatat meningkat menjadi 922,6 trilliun di 2016. Tahun ini Bekraf menargetkan kontribusi ekonomi kreatif mencapai 1,041 trilliun. Industri kreatif diharapkan menyerap 18,2\% tenaga kerja dan menyubang US\$ 23,7 milliar ekspor nasional, sedangkan di 2019, kontribusinya ditargetkan senilai Rp. 1.123 trilliun terhadap PDB dan menyumbang ekspor US\$25,1 milliar".30

Fakta bahwa potensi pasar karya kreatif di dalam dan luar negeri sangat besar dan memiliki kecendrungan terus berkembang, semakin memperkuat alasan pentingnya perlindungan hak kekayaan intelektual atas produk ekraf, dengan tujuan agar pencetus ide kreatif dan inovasi tersebut mendapat manfaat ekonomi atas karya intelektual. 31

29 Ni Ketut Supasti Dharmawan, Dkk, Kepariwisataan Berbasis Budaya Kuliner Dalam Perspektif Hukum kekayaan Intlektual, Proseding APHKI, Lombok, 2017, hlm. 5.

30 Desy Setyowati dan Metta Dharmasaputra, Bekraf Targetkan Industri Kreatif Sumbang PDB Rp. 1.000 trillun, D. Katadata.co.id, 26 Februari 2018.

${ }^{31}$ Sulasi Rongiyati, Perlindungan Hukum Hak Kekayaan Intelektual Pada Produk Ekonomi Kreatif, Jurnal , Negara Hukum, Vol.9, No.1 Juni 20 18, hal 40

Ganefi, Sinergitas Industri Kreatif Berbasis Hak Kekayaan Intelektual Dalam Menunjang Pariwisata 
Supremasi Hukum : Jurnal Penelitian Hukum

p-ISSN: 1693-766X ; e-ISSN: 2579-4663, Vol. 28, No. 2, Agustus 2019, 187-203

Peningkatan kontribusi industri kreatif yang menunjukkan kenaikan signifikan dari tahun ketahun, ternyata tidak dibarengi oleh upaya perlindungan hak kekayaan intelektual (HKI). Hal ini terlihat dari perbandingan antara pelaku ekomoni kreatif yang jumlahnya mencapai 16,7 juta, hanya 17 persen atau sekitar 2,84 juta saja yang mendaftarkan Hak Kekayaan Intelektualnya. Fakta ini sangat berbanding terbalik dengan pendaftaran paten khususnya untuk negara-negara asia tenggara. "Sungguhpun Indonesia pada tahun 1997 telah meratifikasi PCT, melalui Kepres No. 6 , ternyata Indonesia sangat tertinggal jauh jika dibandingkan dengan Malaysia yang memasukkan 310 paten, kemudian Singapura memasukkan 837 paten, disusul Thailand dengan 72 paten, Filipina 32 paten, Vietnam 17 paten, sedangkan Indonesia hanya mendaftarkan paten sebanyak 13 pengajuan."32

Rendahnya perlindungan Hak Kekayaan Intelektual di Indonesia, ternyata membawa dampak terhadap banyaknya keunikan-keunikan seperti bidang seni budaya tradisional daerah yang memiliki nilai seni tinggi dicuri/diklaim oleh negara lain sebagaimana dikemukanan sebagai berikut: “..... Batik dari Jawa oleh Adidas, Naskah kuno dari Riau oleh Pemerintah Malaysia, Naskah kuno dari Sumatera Barat oleh Pemerintah Malaysia, Naskah kuno dari Sulawesi Selatan Pemerintah Malaysia, Naskah kuno dari sulawesi Tenggara oleh Pemerintah Malaysia, Rendang dari Sumatera Barat oleh oknum WN Malaysia, Sambal Bajak dari Jawa Tengah oleh Oknum WN Belanda, Sambal Petai dari Riau oleh Oknum WN Belanda, Sambal Nanas dari Riau oleh Oknum WN belanda, Tempe dari jawa oleh Beberapa Perusahaan asing, Lagu Rasa Sayang-Sayange dari Maluku oleh Pemerintah Malaysia, Tari Reok Ponorogo dari Jawa timur oleh Pemerintah Malaysia,.......". ${ }^{33}$

Klaim/pencurian seni dan budaya tradisional diberbagai daerah sebagai warisan leluhur sebagai indikasi geografis tentu sangat merugikan bagi bangsa Indonesia, terlebih lagi pemerintah saat ini sedang giat-giatnya membangun sektor pariwiata yang diharapkan sebagai salah satu sumber pendapatan negara disamping pembukaan lapangan usaha dan lapangan kerja, juga sebagai sumber devisa negara terutama pendapatan negara diluar sektor pajak demi kelangsungan pembangunan nasional. Keprihatinan terhadap pencurian seni budaya tradisional dari berbagai daerah di tanah air terutama oleh negara Malaysia beberapa waktu lalu, apabila tidak segera disikapi secara bijak, bukan tidak mungkin dikemudian hari bisa ratusan bahkan ribuan kekayaan asli Indonesia menjadi milik negara lain. Menurut guru besar emeretus Fakultas Hukum Universitas Padjadjaran Bandung, Eddy Damian, "Akibat berbagai kelemahan, seni budaya Indonesia sering diklaim negara lain, karena datanya lemah, Indonesia tidak berdaya. Padahal jika memiliki daftar kekayaan intelektual, termasuk seni budaya, daftar itu bisa disampaikan kepada organisasi Hak Kekayaan Intelektual Dunia di

32 M. Taufikul Basari, 10 Negara Dengan Aplikasi Paten Terbanyak, Indonesia Nomor Berapa, M. Bisnis. Com, 02 Juni 2014.

33 Candra Irawan, Politik Hukum Hak Kekayaan Intlektual Indonesia, Kritik Terhadap WTO//TRIPS, Agreement dan Upaya Membangun Hukum Kekayaan Intelektual Demi Kepentingan Nasional, Mandar Maju, 2011, hlm. 252.

Ganefi, Sinergitas Industri Kreatif Berbasis Hak Kekayaan Intelektual Dalam Menunjang Pariwisata 
Supremasi Hukum : Jurnal Penelitian Hukum

p-ISSN: 1693-766X ; e-ISSN: 2579-4663, Vol. 28, No. 2, Agustus 2019, 187-203

Geneva untuk mendapatkan pengakuan internasional. Namun hal itu belum dilakukan Indonesia". ${ }^{34}$

Hal tersebut menunjukkan bahwa ketidak pedulian pemerintah daerah tehadap seni budaya di daerahnya yang menyebabkan tidak terinventarisnya berbagai aneka seni budaya yang telah lama tumbuh dan berkembang di tengahtengah masyarakat yang diwariskan leluhur kepada anak cucu untuk dijaga dan dilestarikan, justru diklaim oleh negara lain sebagai milik mereka. Bahkan oleh negara yang bersangkutan di diproklamirkan sebagai identitas bangsa. Seperti misalnya tari reog Ponorogo dijadikan ikonnya tahun pariwisata negara malaysia dengan slogan "Trully Of Asia". Padahal berdasarkan kewenangan sebagaimana tertuang dalam Undang-Undang Kepariwisataan, seharusnya pemerintah dapat melakukan berbagai upaya publikasi secara masif keberbagai negara, baik melalui media masa, buku-buku, maupun melalui ajang-ajang pameran kepariwisataan.

\section{Faktor-Faktor Penyebab Rendahnya Perlindungan Hak Kekayaan Intelektual Terhadap Industri Kreatif Yang Berbasis Pariwisata}

Industri kreatif merupakan salah satu sektor yang diharapkan pemerintah dalam pembangunan ekonomi terutama pembukaan lapangan usaha, penyerapan tenaga kerja serta sebagai sumber Produck Domestik Bruto (PDB). Namun demikian kondisi industri kreatif pada saat ini justru banyak menghadapi masalah terutama dalam hal pendaftaran Hak Kekayaan Intelektual. Sebagian besar pelaku yang belum daftar dari subsektor film, animasi, dan video sebanyak $21,08 \%$. Subsektor lain adalah kuliner sebanyak 19,75\%; televisi dan radio $16,59 \%$; penerbitan 15,86\%; fesyen 14,14\%; desain produk $11,56 \%$; desain komunikasi visual $7,25 \%$; musik 6,88\%; kriya 6,69\%; desain interior 5,45\%; serta arsitektur 3,64\%. (Baca: Musim Semi Industri Kreatif di Indonesia). Bertolak dari rendahnya pendaftaran Hak kekayaan Intelektual yang hanya sebesar 17 persen dari total 16,7 juta pelaku industri kreatif, telah memberikan gambaran betapa perlindungan hak kekayaan intelektual sangat memprihatinkan di tengah-tengah gencarnya upaya pemerintah membangun sektor industri kreatif sebagai salah satu andalan di masa depan untuk pembukakaan lapangan usaha, penyerapan tenaga kerja dan sebagai sumber penerimaan negara di luar penerimaan pajak, perikanan, dan pertambangan. Oleh karena itulah dimasa pemerintahan Ir. Joko Widodo, arah dan kebijakan pembangunan industri kreatif dikelola sendiri oleh suatu lembaga diluar struktur pemerintahan/non departemen yang disebut Badan Ekonomi kreatif (BEKRAF).

Pembentukan Bekraf diharapkan bukan saja sebagai falisitator bagi pelaku industri kreatif dalam mengembangkan dan memasarkan produk-produk kreativitasnya, juga ditujukan sebagai jembatan penghubung beberapa lembaga yang berkaitan dengan industri kreatif, seperti, Departemen Perindustrian, perdagangan, Kepariwisataan dan Departemen Hukum dan Hak Asasi Manusia, khususnya yang berhubungan dengan Hak Kekayaan intelektual (HKI), sehingga hambatan-hambatan yang menyebabkan kurang atau tidak berkembangannya

${ }^{34}$ Eddy Damian, Perlindungan Budaya Indonesia Lemah, Kompas.com, 31 Agustus 2009.

Ganefi, Sinergitas Industri Kreatif Berbasis Hak Kekayaan Intelektual Dalam Menunjang Pariwisata 
Supremasi Hukum : Jurnal Penelitian Hukum

p-ISSN: 1693-766X ; e-ISSN: 2579-4663, Vol. 28, No. 2, Agustus 2019, 187-203

industri kreatif dapat diatasi dengan kesinergitasan antar berbegai lembaga yang berkompeten dalam pembangunan industri kreatif.

Optimisme seperti yang diharapkan pemerintahan Ir.Joko Widodo yang memasuki usia 4 tahun, akan tercipta industri kreatif terutama yang berkenaan dengan perlindungan hak kekayaan intelektual tidak sepenuhnya berhasil. Bahkan boleh dibilang keadaannya sama seperti pemerintahan-pemerintahan sebelumnya. Dengan persentase $17 \%$ saja pelaku industri kreatif yang mendaftarkan hak kekayaan intelektualnya merupakan sebuah bukti betapa perlindungan Hak Kekayaan Intelektual menjadi masalah serius bagi perkembangan dan kemajuan industri kreatif di masa yang akan datang. Hal ini diakui oleh Kepala Badan Ekonomi Keatif, Ricky J. Pesik, bahwa saat ini masalah Perlindungan Hak Kekayaan Intelektual menghadapi masalah yang sangat berat, dan masih jadi PR kita, padahal manfaat HKI sangat besar. Jika mengutif yang dikemukakan oleh, Absari Krisdianti, Faktor-faktor penyebab rendahnya pendaftaran Hak Kekayaan Intelektual (HKI), meliputi :

1. Rendahnya Kesadaran Masyarakat untuk mendaftarkan hak intelektualnya,

2. Minimnya pengetahuan masyarakat tentang Hak Kekayaan Intelektual (HKI)

3. adanya anggapan bahwa pengurusan Hak Kekayaan Intelektual membutuhkan biaya yang lumayan

4. Waktu pengurusan membutuhkan waktu lama dan berbelit.

Rendahnya kesadaran masyarakat untuk mendaftarkan hak intelektual, terjadi akibat kurang pemahaman akan arti pentingnya hasil kreativitas mereka untuk dilindungi secara hukum dan jika terjadi pencurian hasil karyanya yang bersangkutan dapat melakukan upaya hukum terhadap pihak-pihak yang melakukan pencurian tersebut. Sedangkan minimnya pengetahuan masyarakat tentang Hak Kekayaan Intelektual, terjadi akibat kurang tersosialisanya hal-hal yang berhubungan dengan aspek-aspek kekayaan intelektual. Keadaan ini menyebabkan sebagian besar pelaku industri kreatif sama sekali tidak tahu manfaat dari hak kekayaan intelektual, bahkan istilah HKI itu sendiri masih asing ditelinga mereka. Adapun bagi sebagian dari pelaku industri kreatif yang mengetahui tentang perlindungan hak kekayaan intelektual, merasa enggan untuk mendaftarkan hasil kreativitas mereka, karena menganggap dalam pengurusannya memerlukan biaya lumayan tinggi. Pengalaman masa lalu dan mungkin sampai saat ini masih terjadi disebagian birokrasi walaupun secara sembunyi-sembunyi, setiapkali berhubungan dengan yang namanya perizinan, masyarakat selalu dikenakan biaya tambahan di luar biaya resmi yang ditetapkan pemerintah, berupa pungutan-pungutan liar (Pungli) sebagai uang "pelicin" dan apabila tidak diberikan, maka segala urusannya akan dipersulit. Bahkan yang lebih ironi lagi justru "uang pelicin" jauh lebih besar nilainya dibanding biaya resmi yang harus dibayar masyarakat. Keadaan ini diperparah lagi dengan sistem birokrasi yang tidak tertata dengan baik, terkadang untuk mendapatkan satu tanda tangan/rekomendasi pejabat yang berkompeten saja, dibutuhkan waktu berharihari, maka tidak mengherankan jika aparatur negara yang seharusnya datang

Ganefi, Sinergitas Industri Kreatif Berbasis Hak Kekayaan Intelektual Dalam Menunjang Pariwisata 
Supremasi Hukum : Jurnal Penelitian Hukum

p-ISSN: 1693-766X ; e-ISSN: 2579-4663, Vol. 28, No. 2, Agustus 2019, 187-203

lebih awal, siap menunggu untuk melayani masyarakat, justru terbalik, masyarakat harus siap menunggu aparatur negara sampai kapanpun yang bersangkutan berkenan untuk membubuhkan tanda tangan di dokumennya. Reformasi birokrasi yang seharusnya bertujuan untuk penyederhanaan sistem pelayanan masyarakat, justru oleh sebagian oknum dibuat berbelit-belit dengan tujuan uang "pelicin" dijadikan acuan dalam setiap proses pengurusan suratmenyurat dan perizinan. Disamping kurangnya kesadaran masyarakat, minimnya pengetahuan tentang hak kekayaan intelektual, beban biaya dalam pengurusan pendaftaran, faktor lainnya adalah jarak antara tempat tinggal pelaku industri kreatif dengan instansi yang mengurusi pendaftaran hak kekayaan intelektual cukup jauh sehingga membutuhkan waktu tempuh yang lama.

Sehubungan dengan permasalahan tersebut di atas, maka Deputi Fasilitasi Hak kekayaan Intelektual dan harmonisasi regualasi membuat terobosan melakukan tugas antara lain : merumuskan, menetapkan, mengkoordinasikan , dan sinkroniasai kebijakan-kebijakan dan program fasilitasi HKI serta sinkronisasi regulasi di bidang ekraf. Program unggulan yang dilakukan Deputi Fasilitasi HKI dan Harmoniassai Regulasi adalah :35

a. Mengadakan konsultasi HKI secara masal dan gratis bagi pelaku ekraf;

b. Desain ulang kemasan produk indikasi geografis;

c. Menyediakan fasilitasi 5000 (Lima Ribu) Sertifikasi Profesi untuk pelaku ekraf;

d. Menyediakan fasilitasi 1000 (seribu) pendaftaran HKI untuk pelaku ekraf, dan

e. Mendirikan Satgas Anti Pembajakan untuk memerangi pelanggaran HKI.

\section{PENUTUP}

Dewasa ini industri kreatif mengalami kemajuan yang sangat pesat, seiring dengan kemajuan industri pariwisata yang dapat diandalkan bukan saja sebagai pembukaan lapangan usaha, lapangan pekerjaan dan sebagai sumber pendapatan negara bahkan lebih jauh lagi, industri kreatif dan industri pariwisata merupakan aset nasional yang senantiasa terbarukan seiring dengan perubahan dan kemajuan peradaban manusia, oleh sebab itu perlu mendapatkan perlindungan yaitu dengan melakukan pendaftaran HKI. Hingga saat ini hanya $17 \%$ dari 16.7 juta pelaku industri kreatif saja yang melakukan pendaftaran hak kekayaan intelektualnya. Faktor rendahnya kesadaran masyarakat/pelaku industri kreatif untuk melakukan pendaftaraan kekayaan intelektualnya disebabkan pertama, rendahnya kesadaran masyarakat untuk mendaftarkan hak intelektualnya, kedua karena minimnya pengetahuan masyarakat tentang Hak Kekayaan Intelektual (HKI), ketiga karena adanya anggapan bahwa pengurusan Hak Kekayaan Intelektual membutuhkan biaya yang lumayan, dan keempat karena waktu pengurusan yang membutuhkan waktu lama dan berbelit.

35 Sulasi Rongiyati, Perlindungan Hukum Hak Kekayaan Intelektual Pada produk Ekonomi Kreatif, Jurnal, Negara Hukum, Vol 9. No.1. Juni 2018, p. 46

Ganefi, Sinergitas Industri Kreatif Berbasis Hak Kekayaan Intelektual Dalam Menunjang Pariwisata 
Supremasi Hukum : Jurnal Penelitian Hukum

p-ISSN: 1693-766X ; e-ISSN: 2579-4663, Vol. 28, No. 2, Agustus 2019, 187-203

\section{DAFTAR PUSTAKA}

Alfons, Maria, 2017, Implementasi Hak Kekayaan Intelektual Dalam Perspektif Negara Hukum, Jurnal Legislasi Indonesia, Vol. 14 (3) September.

Asdhiana, I Made, 2018, "Pariwisata dan Industri Kreatif Jalan Bersama", diunduh tanggal $12 \quad$ Juni 2018 dari https://travel.kompas.com/read/2014/08/21/161000627/Pariwisata.da n.Industri.Kreatif.Jalan.Bersama.

Basari, M. Taufikul, 2014, 10 Negara Dengan Aplikasi Paten Terbanyak, Indonesia Nomor Berapa, M. Bisnis. Com, 02 Juni 2014.

Cahyani, Afni Regita, 2019, Strategi Indonesia Dalam Mendorong Sustainable Competitive Advandtage Ekonomi Kreatif Subsektor Fashion: Kebijakan Industri dan Diplomasi Perdagangan, Universitas Gajah Mada, Tesis, 2018, diunduh tanggal 26 Januari 2019 dari http://etd.repository.ugm.ac.id/

Damian, Eddy, 2009, Perlindungan Budaya Indonesia Lemah, Kompas.com, 31 Agustus.

Departemen Perdagangan Republik Indonesia, 2008, Pengembangan Ekonomi Kreatif Indonesia 2025, Jakarta, Depdag RI.

Dharmawan, Ni Ketut Supasti., dkk, 2017, Kepariwisataan Berbasis Budaya Kuliner Dalam Perspektif Hukum kekayaan Intlektual, Proseding APHKI, Lombok, 2017.

Diana, Putri, 2017, Peran Dan Pengembangan Industri Kreatif Dalam Mendukung Pariwisata Di Desa Mas Dan Desa Peliatan, Ubud, Jurnal Analisis Pariwisata ISSN: 1410 - 3729, Vol. 17 No. 2.

Djamal, 2017, Pemberlakuan hukum kekayaan Intelektual Dalam Praktik Di Indonesia, International Conference Proceding, Faculty of Law, University of Mataram in coroperation with Association of Intelectual Property Lecturer of Indonesia.

Hakim, Lukman, 2010, Industri Pariwisata Dan Pembangunan Nasional, Among Makarti, Vol.3 No.5 Juli.

Hamalik, Oemar, 1978, Travel dan Tour, Azas, Metode dan Teknis, Jakarta: Pradnya Paramitha.

Ganefi, Sinergitas Industri Kreatif Berbasis Hak Kekayaan Intelektual Dalam Menunjang Pariwisata 
Supremasi Hukum : Jurnal Penelitian Hukum

p-ISSN: 1693-766X ; e-ISSN: 2579-4663, Vol. 28, No. 2, Agustus 2019, 187-203

Irawan, Candra, 2011, Politik Hukum Hak Kekayaan Intlektual Indonesia, Kritik Terhadap WTO//TRIPS, Agreement dan Upaya Membangun Hukum Kekayaan Intelektual Demi Kepentingan Nasional, Mandar Maju.

Lindsey, dkk. (editor), Hak Kekayaan Intelektual Suatu Pengantar, Bandung: PT. Alumni, 2011.

Mudrikah, Alfiah dkk., 2014, Kontribusi Sektor Pariwisata Terhadap Gdp Indonesia Tahun 2004 - 2009, Economics Development Analysis Journal (EDAJ) 3 (2) (2014).

Mukti Fajar ND, 2016, UMKM Di Indonesia Perspektif hukum Ekonomi, Pustaka Pelajar, Yogyakarta.

Ningsih, Caria, 2014, Sinergitas Industri Kreatif Berbasis Pariwisata Dengan Strategi Pembangunan Industri Nasional Menuju Globalisasi. Jurnal Manajemen Reseort \& Leisure, Vol.11, No.1, April.

Nugroho, Sigit, 2015, Perlindungan Hak Kekayaan Intelektual Dalam Upaya Peningkatan Pembangunan Ekonomi Di Era Pasar Bebas Asean, Supremasi Hukum :Jurnal Penelitian Hukum, 24, No. 2, Agustus.

Raharjo, Satjipto, 1983, Permasalahan Hukum di Indonesia, Bandung: Alumni.

Rongiyati, Sulasi, 2018, Pelindungan Hukum Hak Kekayaan Intelektual Pada Produk Ekonomi Kreatif, Jurnal NEGARA HUKUM: Vol. 9, No. 1, Juni.

Rois, Muhammad Fahmi dan Kholis Roisah, Perlindungan Hukum Kekayaan Intelektual Kerajinan Kuningan Tumang, Kanun Jurnal Ilmu Hukum, Vol. 20, No. 3, (Desember, 2018), doi: https://doi.org/10.24815/kanun.v20i3.11717.

Saliman, Abdul Rasyid, 2011, Hukum Bisnis untuk Perusahaan: Teori dan Contoh Kasus, Edisi kedua, Cetakan ke-6, Jakarta: Prenada Media Group.

Sanjiwani, Putri Kusuma, 2016., Hak Kekayaan Intelektual Dalam Industri Pariwisata Studi Kasus: Perlindungan Hukum Pemanfaatan Local Genius dalam Produk Pengusaha Lokal, Jurnal Ilmiah Hospitality Management ISSN 2087 - 5576 Vol. 7 No. 1, Desember.

Setyowati, Dewi dan Metta Dharmasaputra, Bekraf Targetkan Industri Kreatif Sumbang PDB Rp. 1.000 trillun, D. Katadata.co.id, 26 Februari 2018.

Setyowati, Dewi dkk., 2019, "Bekraf Targetkan Industri Kreatif Sumbang PDB Rp 1.000 Triliun”, diunduh tanggal 27 Januari 2019 dari

Ganefi, Sinergitas Industri Kreatif Berbasis Hak Kekayaan Intelektual Dalam Menunjang Pariwisata 
Supremasi Hukum : Jurnal Penelitian Hukum

p-ISSN: 1693-766X ; e-ISSN: 2579-4663, Vol. 28, No. 2, Agustus 2019, 187-203

https://katadata.co.id/berita/2018/02/26/bekraf-targetkan-industrikreatif-sumbang-pdb-rp-1000-triliun

Sudaryat, dkk., 2010. Hak Kekayaan Intelektual, Cetakan I, Bandung: Oase Media, 2010 .

Susyanti, Jeni, 2014, Model Pendampingan Sektor Paeriwisata Secara Integratif, Studi Kasus Pada Pelaku Bisnis Ekonomi Kreatif di Malang, Seminar Nasional Riset Inovatif II, ISSN: 2339-1553.

Wijanarko, Tulus, 2018, Pertumbuhan Pariwisata Indonesia Peringkat 9 Di Dunia, Harian Tempo.co, Selasa 23 Oktober 2018, diunduh tanggal 20 April 2019 dari https://travel.tempo.co/read/1139099/pertumbuhanpariwisata-indonesia-peringkat-9-di-dunia

Ganefi, Sinergitas Industri Kreatif Berbasis Hak Kekayaan Intelektual Dalam Menunjang Pariwisata 